\title{
RESEARCH METHODS AND TECHNIQUES IN MANAGEMENT PRACTICE IN THE ERA OF INDUSTRY 4.0
}

\author{
Henryk DŹWIGOŁ \\ Silesian University of Technology, Gliwice, Poland; London Academy of Science and Business, London, United \\ Kingdom; Sumy State University, Sumy, Ukraine; henryk.dzwigol@poczta.fm, ORCID: 0000-0002-2005-0078
}

Purpose: The aim of the article was to indicate research methods and techniques used in management practice while taking into account the assumptions of Industry 4.0.

Design/methodology/approach: In order to identify research methods and techniques, the author of the article made use of a survey questionnaire addressed to practitioners who were his target group: 52 foreign companies, 183 domestic companies. As a result of the research effort undertaken, the answers of 118 representatives of management science practitioners were analysed.

Findings: The conclusions of the research indicated that the most important methods, according to management practitioners, were: observation, interview and documentation analysis. However, the most frequently used research techniques in practice include: analysis of business opinions, a probation period at the workplace, situation-related interview, knowledge test in a specific field, task-related behaviour samples, task skills test and analysis of informal client opinions.

Research limitations/implications: At the stage of defining a research problem, it is now difficult to choose a single method that provides a complete and thorough diagnosis of the problem. It is, therefore, necessary to use a variety of research methods which provide a comprehensive response to the research problem posed.

Practical implications: Optimization of strategic decision-making processes will depend on the situation the company is in. In a crisis situation, the most important thing is to make quick decisions triggering actions that would improve the company's competitive edge. That requires undertaking actions 'in parallel', i.e. not only reacting to the problems resulting from the current situation but also solving the issues related to the future, e.g. Industry 4.0, which is considerably difficult.

Social implications: When analysing the obtained results, management practitioners stress that it is necessary to develop a model, procedure, tool, approach to the research process. Moreover, respondents also believe that the developed model, procedure, tool or approach in the selection of methods to the research process significantly affects the quality and practical use of research results.

Originality/value: The analysis of the results clearly indicates the use of research techniques that are close to the task processes of companies and verify the competence of employees. Conclusions resulting from the analysis of national and foreign literature on research process methodology indicate the need to address the problem of using diversified research methods providing a comprehensive response to the problem posed in the context of Industry 4.0.

Keywords: Methods, research techniques, research process, Industry 4.0. 


\section{Introduction}

The methodology of strategic management determines all the principles of its implementation, i.e. logic, language, methods and techniques, instruments. The methodology, in its sense, serves as an intermediary between an object and a subject of strategic management, it constitutes a kind of global tool through which the object of strategic management is influenced by the subject of strategic management (Ansoff et al., 2018). The strategic management system means a coherent set of elements of strategic management, structured on the basis of a strategic attitude and circumstances, capable of performing the functions of strategic planning, organising, motivating, controlling and other management-related processes (Coleman, and Casselman, 2016). Strategic company management is a dynamic and deliberately targeted process of performing the necessary functions allowing culturally conditioned coordination and synchronization of human work and economical use of economic resources, by shaping their potential, allowing both to take advantage of the opportunities and mitigate the threats occurring or likely to occur in the company's environment (Banker et al., 2018). Contemporary organisations have been struggling with problems resulting directly from changes in their environment. Continuous development and environmental conditions prompt companies to seek new trends and management methods. Taking that into account, research methods and techniques in management sciences are aimed at finding out about rules and principles that govern organisations, and at changing the said organisations for better (Quinlan et al., 2019).

A method can be defined as a conscious and resolute way in which a researcher acts or behaves in order to achieve a defined goal (Dźwigoł, 2019a). A technique, on the other hand, can be defined as an instrument, tool used to solve appearing problems (Dzwigol, 2019a; 2019b; 2020a; 2020b; 2020c; Dzwigoł, \& Wolniak, 2018; Dzwigoł, \& Dzwigoł-Barosz, 2018). However, from the practical point of view, it is not easy to distinguish between a method and a technique. Regardless of a researcher's decision about applying a research method or a research technique, the researcher is always obliged to implement a determined research process (Bryman, 2006; Vaivio et al., 2010). The research process consists of numerous elements; the said elements should be meticulously planned on the basis of continuous choices. The said choices are to be made in consideration of reliability and credibility of research findings (Cooke, 2003).

When analysing the literature on phenomena and problems of interest to the researcher and their subsequent solutions, the researcher must also be subject to the principle of intersubjective verifiability. According to this principle, the results of someone else's research should be verified and checked (Grudzewski, and Hejduk, 2007). Research methodology and selected research methods and techniques within its framework should support the process of management in practice, including for example Industry 4.0 or the crisis. 
One cannot discuss the assumptions of Industry 4.0 in isolation from the current crisis situation.

It should be stated that in spite of some criticism, management science and its methods lead to increased efficiency and competitiveness of enterprises. It is worth noting, however, that management methods are not and cannot be universal. These methods must change over time, just as the company does with the time.

Most disciplines of science have separate, relevant and diverse cognitive methods to solve or diagnose a research problem, whereas the management methodology is neither permanent nor universal. Management uses methods specific to other sciences, including psychology, social sciences, statistics, econometrics or economics. Management methodology is a set of reflections on the transformations taking place over the years in management methods, which allows exploring the state in which a company is in. It is constantly being enhanced with new methods characterized by different cognitive and practical efficiency. Continuous development of diagnostic instruments is primarily determined by the changes taking place in the environment.

The literature on management sciences has often stressed the need to use, at the same time, numerous different methods of exploring and developing organisations (Labarca, 2017; Patton, 2002). The literature has also pointed out that there is a need for simultaneous use of many mutually verifying and correcting methods (Koźmiński, 2011). Therefore, the aim of the article is to indicate research methods and techniques used in management practice in the era of Industry 4.0 .

\section{Industry 4.0 in a changing economic environment}

Industry 4.0 - The Fourth Industrial Revolution - a generic concept relating to the concept of 'industrial revolution' in connection with the modern mutual use of automation, data processing and exchange, and manufacturing techniques. By definition, it is an aggregate term for the techniques and principles of value chain organisation that jointly use or apply cyberphysical systems, the internet of things and cloud computing - 2011 Germany (Lee, 2013).

It has been assumed that in the area of Industry 4.0, the company's production system shall consist of an information system and numerically controlled machines that will operate in an autonomous manner and display elements of artificial intelligence (Wittbrodt, Łapuńka). Due to the specific character of production systems in different industries, the term Industry 4.0 cannot, in principle, be generalised. (Kagermann, Wahlster, Helbig, 2013; Lasi, Fettke, Kemper, Feld, Hoffmann, 2014; Schmidt, Härting, Reichstein, Neumaier, Jozinovi, 2015). 
Consequently, Industry 4.0 should be considered on a case-by-case basis, according to the needs of the company in question. The implementation of this idea should make it possible to develop intelligent production systems which, in addition to the aforementioned autonomy, will have the properties of self-configuration, self-control or self-repair. Industry 4.0 is currently one of the most frequently discussed topics among practitioners and researchers, making it a priority for many research centres and companies. The concept of Industry 4.0 covers areas which include numerous technologies and related paradigms. The main elements that are closely related to the idea of Industry 4.0 include: industrial internet of things, cloudbased production, intelligent factories, cyber-physical systems or social product development (Hermann, Pentek, Otto, 2015; Dzwigoł, \& Dzwigoł-Barosz, 2020; Dzwigoł et al., 2019a; 2019b; 2019c; 2020a; 2020b; Kwilinski, 2017; 2018a; 2018b; 2018c; 2019; Kwilinski et al., 2019a; 2019b; 2019c; 2019d; 2020; Lakhno et al., 2018; Miśkiewicz, 2018; 2019; 2020; Miśkiewicz, \& Wolniak, 2020; Tkachenko et al., 2019a; 2019b; Yakubovskiy et al., 2017).

The development of theoretical-methodological aspects of strategic change management in an enterprise under the conditions of 'Industry 4.0' must take into account the current new social, economic and business-related reality. One should try to answer the following question: Are we able to develop a research methodology and select research methods and techniques to support management in conditions of crisis and Industry 4.0?

One question that needs to be answered is: what approach, methods and techniques of research should be used in the process of strategic management under conditions of, perhaps, the greatest economic crisis in history and, in addition, to take into account the assumptions of Industry 4.0?

Taking into account the above considerations, an attempt should be made to develop a new strategic management concept, i.e. assumptions for a new concept of strategic management in conditions of crisis and industry 4.0.

It seems necessary to adopt certain assumptions in the process of developing a new concept of strategic management in the context of Industry 4.0.:

- developing new methods of management in crisis conditions,

- developing a new research methodology to support management in practice,

- changes to the process of creating sustainable development assumptions,

- making use of time management in economic processes,

- making use, within the scope of strategic communication, of the following features: communication, automation, robotisation and computerisation as basic factors within the development process,

- searching common areas between natural and artificial intelligence,

- the inclusion of artificial intelligence in strategic change management in the enterprise and economy,

- changes to the process of knowledge management,

- enhancing social participation in the management processes. 
In order to optimise the process of making strategic decisions, a modern manager must consider a number of factors taking into account the current situation in which these decisions are made, i.e. the crisis and Industry 4.0. The essence is to select appropriate methods and techniques to support the decision-making process. It is important that these tools and methods are proven in practice, as experimenting in an ever-changing environment may be dangerous from the point of view of the effectiveness of the designed strategy.

\section{Research methods}

The conclusions of the analysis of national and foreign literature on research methods and techniques in management sciences indicate the need to diagnose the use of methods and techniques in economic practice. Therefore, the research problem is formulated as follows: Which of the research procedures, methods and techniques are used in management practice?

In view of the above, the article raised the following research questions:

1. Which research procedures are used in management practice?

2. Which research methods are used in management practice?

3. Which research techniques are employed in management practice?

4. Is verification of the developed methods, models or procedures a prerequisite for combining learning and management practice?

5. Is it necessary to develop a model, procedure, tool or approach to the research process itself (e.g. procedures supporting the selection of appropriate techniques/methods for a given issue)?

In order to obtain answers to the research questions submitted, the research was conducted by means of an anonymous questionnaire distributed in a paper form sent by traditional mail and by electronic mail to e-mail addresses derived from an e-mail database gathered earlier. The research was conducted in the period from October 2016 to April 2018.

The questionnaire consisted of four parts. The first part included general questions about conducting research and using available methods and techniques in practice (6 questions), the second one was devoted to the importance of using methods and techniques in the research process in the management and quality sciences ( 2 questions), the third one consisted of questions about improving the level of conducted research processes (4 questions), while the fourth one included demographics (5 questions). The questionnaire consisted mostly of closed questions (8 questions), single or multiple choice, but also open questions (5 questions). They were arranged in the form of a matrix based on the five-point Likert scale (4 questions) (Dźwigoł, 2018). 
Quantitative research (questionnaire) was addressed to management science practitioners, being the target group and covering: 52 foreign companies, 183 domestic companies. As a result of the research effort, 196 representatives of management science practitioners were examined. After initial verification, 118 correctly filled-in questionnaires were admitted for further research analysis.

\section{Research results}

\subsection{Which research procedures are used in management practice?}

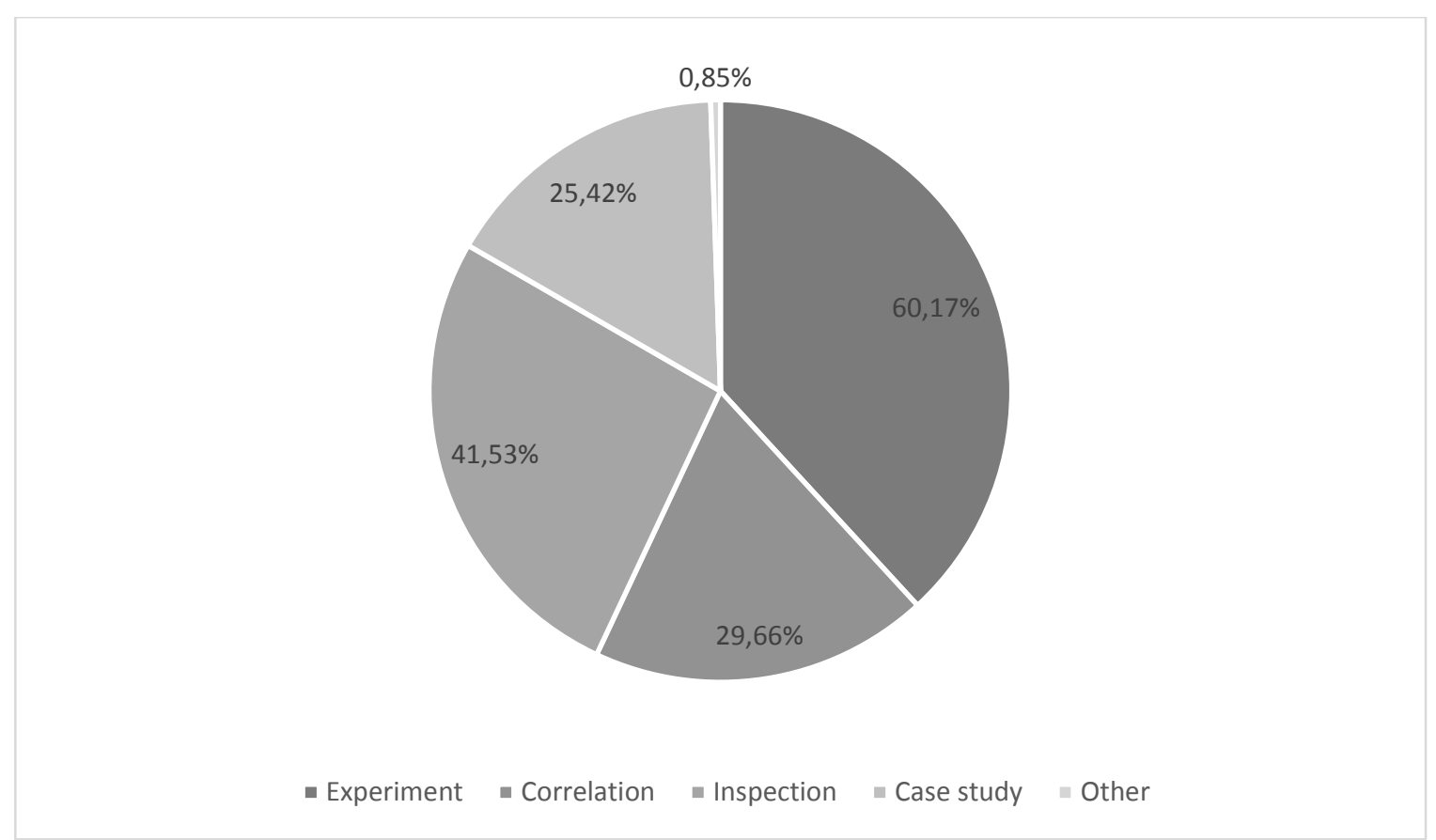

Figure 1. Research procedures employed in management practice. The author's own research.

By analysing the results obtained, it can be unequivocally stated that all the research procedures mentioned are used in economic practice. The above thesis can also be confirmed in the subject-related literature, where it is often indicated that in order to fully and thoroughly diagnose a research problem, it is necessary to apply diversified research methods providing a comprehensive response to the problem. Due to the specific nature of management, it is necessary to use a wide range of tools to identify both universal and specific elements of a given process or area.

Moreover, the introduction of innovative technical solutions in the managed infrastructure requires obtaining optimal knowledge before taking actions, the latter resulting in investment expenditure on a wider scale. 


\subsection{Which research methods are used in management practice?}

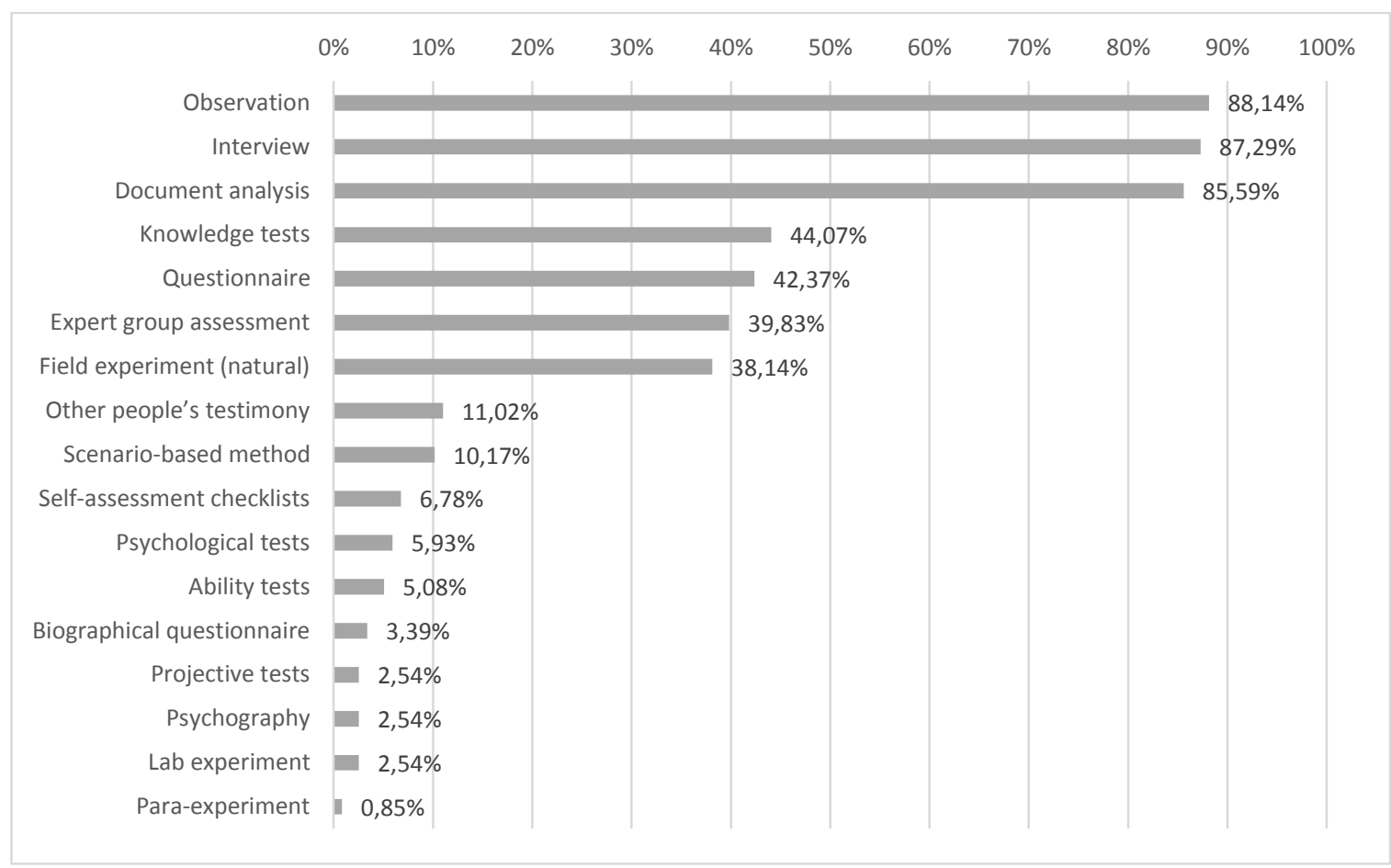

Figure 2. Research methods used in management practice. The author's own research.

When analysing the results obtained, it can be clearly stated that the most frequently used research methods in economic practice are: observation, interview and documentation analysis. Management practitioners indicate that the popularity of these methods is associated with the simplicity of their use. Moreover, the most frequently used methods also include: knowledge test, survey, expert group assessment or field experiment. It should also be emphasized that in the surveyed companies not one, but several research methods are applied. Only such a wide range of research tools and methods makes it possible to match them appropriately to the issues, and find an effective solution.

\subsection{Which research techniques are employed in management practice?}

The most frequently used research techniques in practice include: analysis of business opinions, probation period at the workplace, situation-related interview, knowledge test in a specific field, task behaviour samples, task skills test and analysis of informal client opinions. The analysis of the results clearly indicates the use of research techniques that are close to the task processes of companies and that verify employees' competencies. Moreover, selected techniques etc. have been, from the practical point of view, empirically verified many a time. The obtained measurement results reflected the actual shape of the examined processes and, what is most important, allowed developing correct conclusions, whereas the latter repeatedly contributed to the optimisation of decision-making processes and business results within the scope of the conducted activity. 


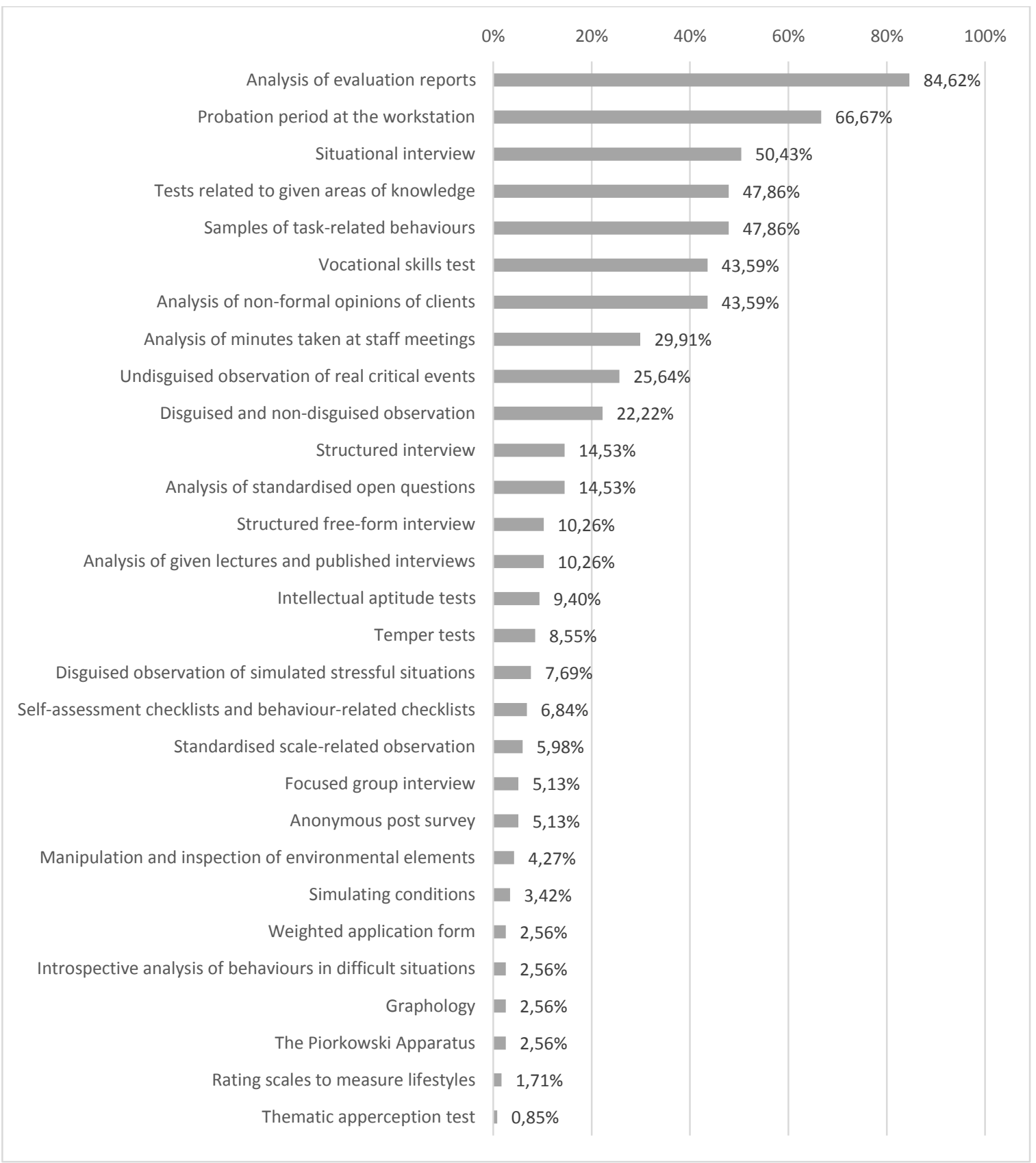

Figure 3. Research techniques used in management practice. The author's own research.

\subsection{Is verification of the developed methods, models or procedures a prerequisite for combining learning and management practice?}

By analysing the results obtained, it can be unequivocally stated that verification of the developed methods, models or procedures is a necessary prerequisite for combining science and management practice (Dźwigoł et al. 2019). The above thesis can also be confirmed in the subject-related literature, where it is often indicated that in order to fully and thoroughly diagnose a research problem, it is necessary to use diversified research methods providing a comprehensive response to the problem. What's more, the development of heterogeneous cognitive, modelling or organisational management methods implies the need to adopt an open 
approach allowing and requiring the combination of multiple approaches and methods, where the verification of both the developed methods, procedures or models in practice is indicated in order to make the research reliable as necessary, and to analyse the selection of chosen methods in terms of the nature of the research before undertaking research work (Thomas 2017; O'Leary 2017).

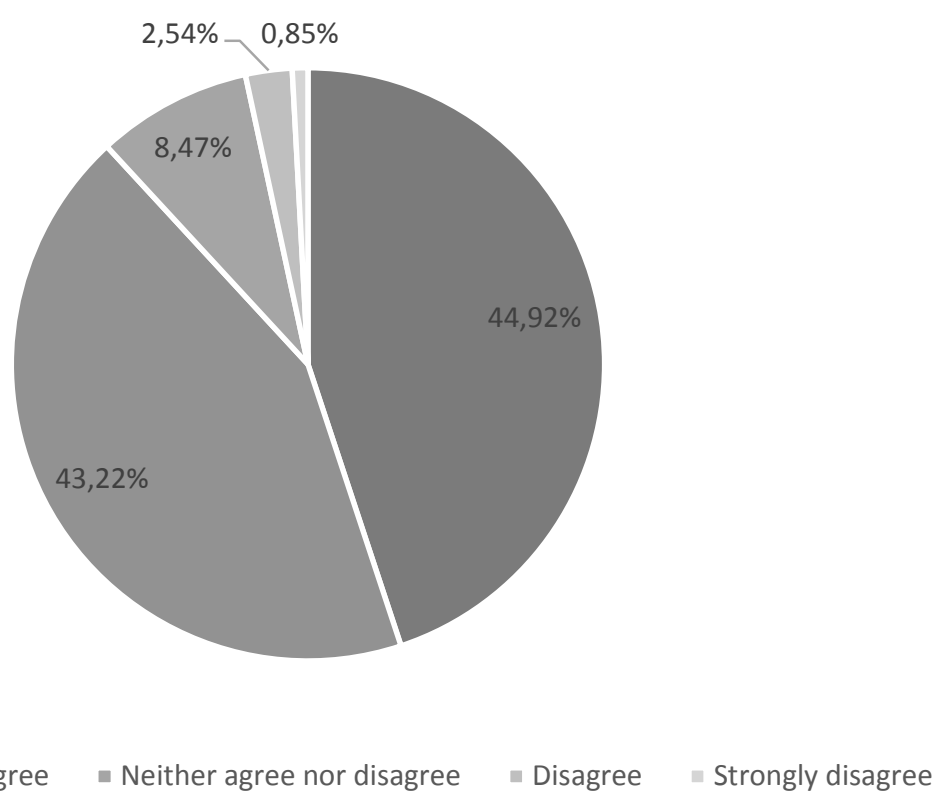

Figure 4. Verification of the developed methods, models or procedures as a prerequisite for combining practical and scientific aspects of management. The author's own research.

\subsection{Is it necessary to develop a model, procedure, tool or approach to the research process itself?}

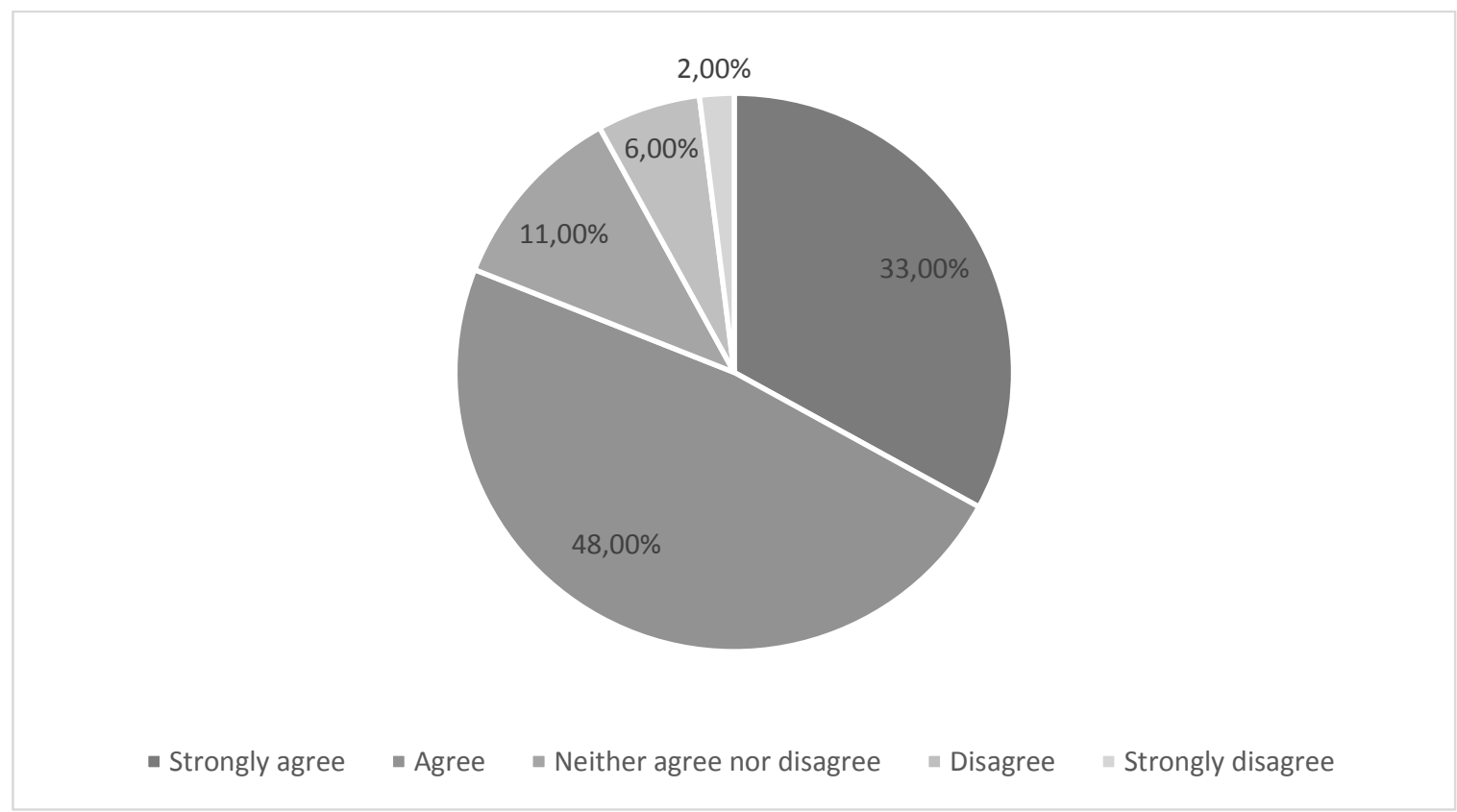

Figure 5. Is it necessary to develop a model, procedure, tool or approach to the research process itself. The author's own research. 
When analysing the obtained results, management practitioners stress that it is necessary to develop a model, procedure, tool, approach to the research process. Moreover, respondents also believe that the developed model, procedure, tool or approach as to the selection of methods to the research process significantly affects the quality and practical use of research results.

\section{Summary and research findings}

The aim of the article was to indicate research methods and techniques used in management practice, taking into account the assumptions of Industry 4.0. Industry 4.0 is not an abstract concept, but real technologies and implementations. Conclusions from the research and literature analysis revealed that the most important methods according to management practitioners are: observation, interview and documentation analysis. In addition, the generally common methods used also include:

- knowledge test,

- survey,

- expert group assessment,

- field experiment.

These are methods to be used in management science. They have also been identified as those that should be used in the research process; however, one should bear in mind that they do not exhaust all the methods that can possibly be used in this area.

Furthermore, it should be pointed out that among the methods that are used in the management sciences, it is possible to identify both methods specific to management only and others, derived from workshops of other sciences. The borrowed methods refer primarily to learning about the organisation and management, while the management's own methods focus on shaping the organisation and management system.

However, the most common techniques used in management practice include:

- analysis of evaluation reports,

- probation period at the workplace,

- situation-related interview,

- test of knowledge in a specific field,

- samples of task-based behaviour,

- task skills test,

- analysis of clients' non-formal opinions.

The analysis of the results clearly indicates the use of research techniques that are close to the task processes of companies and that verify employees' competencies. 
The results obtained confirm extensive literature research on research methodology, where it is noted that the use of many different methods in the research process allows for a comprehensive approach to the research problem and provides a more complete picture.

Conclusions from the analysis of national and foreign literature on research process methodology indicate the need to address the problem of using diversified research methods providing a comprehensive response to the problem.

At the point of defining a research problem, it is currently difficult to select a single method that will provide a complete and thorough diagnosis of the problem. It is therefore necessary to use various research methods which provide a comprehensive response to the posed research problem. Moreover, $89 \%$ of the surveyed management practitioners believe that there is a need for a developed model, procedure, tool or approach supporting the appropriate selection of methods for the research process.

Optimization of strategic decision-making processes will depend on the situation the company is in. In a crisis situation the most important thing is to make quick decisions triggering actions that would improve the company's competitive edge. That requires undertaking actions 'in parallel', i.e. not only reacting to the problems resulting from the current situation, but also solving the issues related to the future, e.g. Industry 4.0, which is considerably difficult. One should hope that the new research methodology and selected research methods and techniques will be able to support this difficult process.

\section{References}

1. Almalki, S. (2016). Integrating Quantitative and Qualitative Data in Mixed Methods Research-Challenges and Benefits. Journal of Education and Learning, 5(3), doi:10.5539/jel.v5n3p288.

2. Ansoff, H.I., Kipley, D., Lewis, A.O., Helm-Stevens, R., \& Ansoff, R. (2018). Implanting Strategic Management. Springer.

3. Banker, R.D., Byzalov, D., Fang, S., \& Liang, Y. (2018). Cost management research. Journal of Management Accounting Research, 30(3), 187-209.

4. Bryman, A. (2006) Integrating quantitative and qualitative research: How is it done? Qualitative Research, 6(1), 3-37, https://doi.org/10.1177/1468794106058877.

5. Coleman, L., \& Casselman, R.M. (2016). Optimizing Decisions Using Knowledge Risk Strategy. Journal of Knowledge Management.

6. Cooke, R.B. (2003). Probabilistic risk analysis: foundations and methods. Rep. Cambridge University Press (CUP).

7. Dźwigoł, H. (2018). Współczesne procesy badawcze w naukach o zarzadzaniu. Uwarunkowania metodyczne i metodologiczne. Warszawa: PWN. 
8. Dzwigoł, H. (2019a). The Concept of the System Approach of the Enterprise Restructuring Process. Virtual Economics, 2(4), 46-70. https://doi.org/10.34021/ve.2019.02.04(3)

9. Dzwigoł, H. (2019b). Research Methods and Techniques in New Management Trends: Research Results. Virtual Economics, 2(1), 31-48. https://doi.org/10.34021/ ve.2019.02.01(2)

10. Dzwigoł, H. (2020a). Innovation in Marketing Research: Quantitative and Qualitative Analysis. Marketing and Management of Innovations, 1, 128-135. http://doi.org/10.21272/ mmi.2020.1-10.

11. Dzwigoł, H. (2020b). Methodological and Empirical Platform of Triangulation in Strategic Management. Academy of Strategic Management Journal, 19(4), 1-8.

12. Dźwigoł, H. (2020c). Interim Management as a New Approach to the Company Management. Review of Business and Economics Studies, 8(1), 20-26. https://doi.org/ 10.26794/2308-944X-2020-8-1-20-26.

13. Dzwigoł, H., \& Dźwigoł-Barosz, M. (2018). Scientific Research Methodology in Management Sciences. Financial and Credit Activity: Problems of Theory and Practice, 2(25), 424-437. https://doi.org/10.18371/fcaptp.v2i25.136508.

14. Dzwigoł, H., \& Dzwigol-Barosz, M. (2020). Sustainable Development of the Company on the Basis of Expert Assessment of the Investment Strategy. Academy of Strategic Management Journal, 19(5), 1-7.

15. Dzwigoł, H., \& Wolniak, R. (2018). Controlling w procesie zarządzania chemicznym przedsiębiorstwem produkcyjnym [Controlling in the management process of a chemical industry production company]. Przemysl Chemiczny, 97(7), 1114-1116. https://doi.org/ 10.15199/62.2018.7.15.

16. Dzwigoł, H., Aleinikova, O., Umanska, Y., Shmygol, N., \& Pushak, Y. (2019b). An Entrepreneurship Model for Assessing the Investment Attractiveness of Regions. Journal of Entrepreneurship Education, 22(1S), 1-7.

17. Dzwigoł, H., Dźwigok-Barosz, M., \& Kwilinski, A. (2020a). Formation of Global Competitive Enterprise Environment Based on Industry 4.0 Concept. International Journal of Entrepreneurship, 24(1), 1-5.

18. Dzwigoł, H., Dzwigol-Barosz, M., Miskiewicz, R., \& Kwilinski, A. (2020b). Manager Competency Assessment Model in the Conditions of Industry 4.0. Entrepreneurship and Sustainability Issues, 7(4), 2630-2644. https://doi.org/10.9770/jesi.2020.7.4(5).

19. Dzwigoł, H., Dzwigoł-Barosz, M., Zhyvko, Z., Miskiewicz, R., \& Pushak, H. (2019c). Evaluation of the Energy Security as a Component of National Security of the Country. Journal of Security and Sustainability Issues, 8(3), 307-317. http://doi.org/10.9770/ jssi.2019.8.3(2).

20. Dzwigoł, H., Shcherbak, S., Semikina, M., Vinichenko, O., \& Vasiuta, V. (2019a). Formation of Strategic Change Management System at an Enterprise. Academy of Strategic Management Journal, 18(SI1), 1-8. 
21. Ferran-Ferrer, N., Guallar, J., Abadal E. and Server, A. (2017). Research methods and techniques in Spanish library and information science journals (2012-2014). Information Research, 22(1).

22. Grudzewski, M.W., and Hejduk, I. (2007). Współczesne kierunki rozwoju nauk o zarządzaniu. In: W.M. Grudzewski (Ed.), Rozwój funkcjonowanie przedsiębiorstw $w$ warunkach globalnej gospodarki światowej. Katowice: Wyższa Szkoła Zarządzania Marketingowego i Języków Obcych.

23. Hair, J.F., Page, M., and Brunsveld, N. (2019). Essentials of Business Research Methods. 4th Edition. New York: Routledge, https://doi.org/10.4324/9780429203374

24. Hermann, M., Pentek, T., Otto, B. (2015). Design Principles for Industrie 4.0 Scenarios: A Literature Review. Technische Universität Dortmund, No. 01.

25. Kagermann, H., Wahlster, W., Helbig, J. (2013). Recommendations for implementing the strategic initiative Industrie 4.0: Final report of the Industrie 4.0 Working Group.

26. Koźmiński, K.A. (2011). Reaktywacja. Warszawa: Poltext.

27. Kwilinski, A. (2017). Development of Industrial Enterprise in the Conditions of Formation of Information Economics. Thai Science Review, Autumn, 85-90.

28. Kwilinski, A. (2018a). Trends of Development of the Information Economy of Ukraine in the Context of Ensuring the Communicative Component of Industrial Enterprises. Economics and Management, 1(77), 64-70.

29. Kwilinski, A. (2018b). Mechanism of Formation of Industrial Enterprise Development Strategy in the Information Economy. Virtual Economics, 1(1), 7-25. https://doi.org/ 10.34021/ve.2018.01.01(1).

30. Kwilinski, A., Dalevska, N., Kravchenko, S., Hroznyi, I., Kovalenko, I. (2019c). Formation of the Entrepreneurship Model of E-Business in the Context of the Introduction of Information and Communication Technologies. Journal of Entrepreneurship Education, 22(SI1), 1528-2651-22-S1-337: 1-7.

31. Kwilinski, A., Dzwigol, H., \& Dementyev, V. (2019f). Transnational Corporations as Entities of International Entrepreneurship. International Journal of Entrepreneurship, 23(SI4), 1-6.

32. Kwilinski, A., Ruzhytskyi, I., Patlachuk, V., Patlachuk, O., \& Kaminska, B. (2019d). Environmental Taxes as a Condition of Business Responsibility in the Conditions of Sustainable Development. Journal of Legal, Ethical and Regulatory Issues, 22(SI2), 1544-0044-22-SI-2-354: 1-6.

33. Kwilinski, A., Volynets, R., Berdnik, I., Holovko, M., \& Berzin, P. (2019e). E-Commerce: Concept and Legal Regulation in Modern Economic Conditions. Journal of Legal, Ethical and Regulatory Issues, 22(SI2), 1544-0044-22-SI-2-357: 1-6.

34. Kwilinski, A., Vyshnevskyi, O., \& Dzwigol, H. (2020a). Digitalization of the EU Economies and People at Risk of Poverty or Social Exclusion. Journal of Risk and Financial Management, 13(7), 142. https://doi.org/10.3390/jrfm13070142. 
35. Labarca, C. (2017). Qualitative Research for beginners. Venezuela: Maracaibo.

36. Lakhno, V., Malyukov, V., Bochulia, T., Hipters, Z., Kwilinski, A., \& Tomashevska, O. (2018). Model of Managing of the Procedure of Mutual Financial Investing in Information Technologies and Smart City Systems. International Journal of Civil Engineering and Technology, 9(8), 1802-1812.

37. Lasi, H., Fettke, P., Kemper, H., Feld, T., Hoffmann, M. (2014). Industry 4.0. Business \& Information Systems Engineering, 6, 239-242.

38. Lee, J. (2013). Industry 4.0 in Big Data Environment. German Harting Magazine, 8-10.

39. Miśkiewicz, R., \& Wolniak, R. (2020). Practical Application of the Industry 4.0 Concept in a Steel Company. Sustainability, 12(14), 5776. https://doi.org/10.3390/su12145776.

40. Miskiewicz, R. (2018). The Importance of Knowledge Transfer on the Energy Market. Polityka Energetyczna, 21(2), 49-62. http://dx.doi.org/10.24425\%2F122774.

41. Miskiewicz, R. (2019). Challenges Facing Management Practice in the Light of Industry 4.0: The Example of Poland. Virtual Economics, 2(2), 37-47. https://doi.org/10.34021/ ve.2019.02.02(2).

42. Miskiewicz, R. (2020). Internet of Things in Marketing: Bibliometric Analysis. Marketing and Management of Innovations, 3, 371-381. http://doi.org/10.21272/mmi.2020.3-27.

43. O'Leary, Z. (2017). The Essential Guide to Doing Your Research Project. London: Sage.

44. Patton, M.Q. (2002). Qualitative research and evaluation methods. Thousand Oaks: Sage Publications.

45. Quinlan, Ch., Babin, B., Carr, J., and Griffin, M. (2019). Business Research Methods. South Western Cengage.

46. Schmidt, R., Möhring, M., Härting, R. C., Reichstein, C., Neumaier, P., Jozinovi, P. (2015). Industry 4.0 - Potentials for Creating Smart Products: Empirical Research Results. In: W. Abramowicz (Ed.), Business Information Systems (pp. 16-27). Springer International Publishing.

47. Thomas, G. (2017). How to Do Your Research Project: A Guide for Students. London: Sage.

48. Tkachenko, V., Kwilinski, A., Klymchuk, M., \& Tkachenko, I. (2019b). The EconomicMathematical Development of Buildings Construction Model Optimization on the Basis of Digital Economy. Management Systems in Production Engineering, 27(2), 119-123. http://doi.org/10.1515/mspe-2019-0020.

49. Tkachenko, V., Kwilinski, A., Korystin, O., Svyrydiuk, N., \& Tkachenko, I. (2019a). Assessment of Information Technologies Influence on Financial Security of Economy. Journal of Security and Sustainability, 8(3), 375-385. http://doi.org/10.9770/ jssi.2019.8.3(7).

50. Tonidandel, S., King, E.B., and Cortina, J. (2016). Big Data Methods: Leveraging Modern Data Analytic Techniques to Build Organizational Science. Organizational Research Methods, 21(3), 525-547, DOI: 10.1177/1094428116677299. 
51. Vaivio, J., \& Sirén, A. (2010). Insights into method triangulation and "paradigms" in interpretive management accounting research. Management Accounting Research, 21(2), 130-141, https://doi.org/10.1016/j.mar.2010.03.001.

52. Wittbrodt, P., Łapuńka, I. (2017). Opole: Instytut Innowacyjności Procesów i Produktów, Politechnika Opolska.

53. Yakubovskiy, M., Liashenko, V., Kamińska, B., \& Kvilinskyi, O. (2017). Economy Modernization of Industrial Regions (Based on the Example of Ukraine). In: P. Głowski, O. Kvilinskyi (Eds.), Economic Transformation in Ukraine: Comparative Analysis And European Experience (pp. 12-29). Warsaw: Consilium Sp. z o.o.

54. Kwilinski, A. (2018c). Mechanism of Modernization of Industrial Sphere of Industrial Enterprise in Accordance with Requirements of the Information Economy. Marketing and Management of Innovations, 4, 116-128. http://doi.org/10.21272/mmi.2018.4-11.

55. Kwilinski, A. (2019). Implementation of Blockchain Technology in Accounting Sphere. Academy of Accounting and Financial Studies Journal, 23(SI2), 1-6. 